\title{
Mineral resources in the Americas - a continent under mutation
}

Ressources minières dans les Amériques: Mutations d'un continent

Recursos mineros en las Américas : mutaciones de un continente

\section{Susanne Berthier-Foglar, Franck Gaudichaud and Sandrine Tolazzi}

Translator. Michael Hinchliffe

\section{OpenEdition}

\section{Journals}

Electronic version

URL: https://journals.openedition.org/ideas/2268

DOI: 10.4000/ideas.2268

ISSN: 1950-5701

This article is a translation of:

Ressources minières dans les Amériques: Mutations d'un continent - URL : https:// journals.openedition.org/ideas/1636 [fr]

Other translation(s):

Recursos mineros en las Américas : mutaciones de un continente - URL : https:// journals.openedition.org/ideas/3096 [es]

Recursos minerais nas Américas. Mutações de um continente - URL : https://

journals.openedition.org/ideas/4709 [pt]

Publisher

Institut des Amériques

\section{Electronic reference}

Susanne Berthier-Foglar, Franck Gaudichaud and Sandrine Tolazzi, "Mineral resources in the Americas - a continent under mutation", IdeAs [Online], 8 | 2016, Online since 06 February 2018, connection on 18 October 2022. URL: http://journals.openedition.org/ideas/2268 ; DOI: https://doi.org/10.4000/ ideas.2268

This text was automatically generated on 18 October 2022.

\section{c)}

Creative Commons - Attribution-NonCommercial-NoDerivatives 4.0 International - CC BY-NC-ND 4.0

https://creativecommons.org/licenses/by-nc-nd/4.0/ 


\title{
Mineral resources in the Americas - a continent under mutation
}

\author{
Ressources minières dans les Amériques: Mutations d'un continent \\ Recursos mineros en las Américas : mutaciones de un continente \\ Susanne Berthier-Foglar, Franck Gaudichaud and Sandrine Tolazzi \\ Translation : Michael Hinchliffe
}

1 At a time when climate change as a global threat is not sufficient incentive to slow either the overconsumption or the rush for energy that are mainly responsible for it, the problem of the development of mineral and energy resources is aggravated by the fact that this development is on the increase not only on the American continent but throughout the world. The extractivist boom of recent years, representing as it does, human activity capable of significantly modifying both the environment and the climate, can be considered as an integral part of the factors that, in the closing years of the $19^{\text {th }}$ century, inaugurated a new geological era named "the Anthropocene" by Nobel prize winner Paul Crutzen. Promoters of the Anthropocene, such as Christophe Bonneuil and Jean-Baptiste Fressoz in their book The Shock of the Anthropocene (London: Verso, 2016; French title: L'événement anthropocène, Paris: Seuil, 2013) see transformations of environment and climate as having a human origin and encourage full awareness of the impact of human activity on global changes which give every sign of having reached a point of no return. Although some scientists remain unwilling to see these changes as anthropic in origin (as Samuele Furfari in Sandrine Tolazzi "Ressources minières et énergétiques: le choc des discours" ["Energy and Mineral Resources: the Clash in Language"]), the vast majority of the community stresses the need to link together generally the dual questions of environmental consequence and the exploitation of resources (as Normand Mousseau in the above mentioned article). It is a fact that environmental considerations are often central to current debates on the development of mineral resources. However, it also appears that, as the interview with Bernadette Mérenne-Schoumaker makes clear, the economic, political, social and geostrategic impact of the recent upsurge of extractive industry on the American continent is bringing about full scale mutations throughout the continent. It was with a 
view to determining the nature of these mutations that the editors of the present dossier organized an initial international symposium on the problem of mineral resources (in Grenoble, June 2014) and, subsequent to that, requested contributions from participants in the symposium and others in order to produce a collection which, hopefully, may stand as exemplifying current scientific discussion. To read the papers, the accounts of scientific monitoring, the interviews gathered here is to see emerging an array of zones of tension involving the play of power between various entities (local communities, corporations, governments at different levels, etc.) but also representations of this play linked to the overall history of mining development.

Mining, and more generally the exploitation of natural resources, lies at the heart of the great geopolitical upheavals and the asymmetric redefinition of North-South relationships: the appropriation, extraction and control of mined wealth have amounted to one of the most powerful movers of colonizing and territorial expansion in the Americas since the $15^{\text {th }}$ and $16^{\text {th }}$ centuries. The thirst for silver and gold has fed into a long term experience of economic, social, political and cultural domination which stretches way beyond the advent of countries' respective Independence and, right up to today, has forged a "tradition" of colonial-type exploitation of resources as a result of which outward facing Latin American economies are dependent on the great industrial powers controlling the international system (see "Domination et extraversion de l'Amérique latine" in Géoplitique des Amériques, ed. Alain Musset, Paris: Nathan, 2014, $4^{\text {th }}$ edition). This model is found not only in North-South relationships on the American continent, but also in the relationship between Latin America and other world economic poles such as Europe and China, and again internally within American countries either in the North or the South. Lucie Genay ("L'extraction d'uranium au Nouveau-Mexique: un symbole de la conquête par l'atome" ["Uranium Mining in New Mexico: a Symbol of the Triumph of the Atom"]) shows how the history of uranium mining in New Mexico confirms that though the stakes of mining themselves have changed, certain neocolonial elements of US nation building have not, but rather perpetuate a heritage of social and racial inequality which gives rise to contrasting reactions among the native American peoples concerned. This "extractivist neocolonialism" is vigorously opposed by a number of social or environmental groups and indigenous Latin-American communities whose activism has resulted in several conflicts both with governments and mining corporations. Confronted with multiple protests, governments throughout the continent have tried several strategies, from repression and institutional containment to moratoriums and the imposition of mining-free zones (Maria Teresa Gutierrez-Haces, "L'investissement étranger et l'activité minière en Amérique latine. Les stratégies gouvernementales dans les conflits avec les compagnies minières" ["Foreign Investment and Mining in Latin America. Government Strategy in Conflicts with Mining Corporations"]). The fact is that whether they call themselves progressive or "national-popular" or conservative, governments have all attempted to cash in on the mineral and primary resource price-boom of recent years, albeit along frequently differing lines in terms of public policy. However, the global crisis and the drop in demand since 2007-2008 have revealed the extent to which American economies obey an income-based and reprimarizing logic contravening any perspective of "durable" or virtuous development. Which raises the question as to whether an alternative model is possible. With its "Plan for Concerted Strategic Action for the Development of the Orinoco Belt and Mining Arc" the Bolívar State government suggests there is. The plan claims to reconcile economic growth and 
alliances with multinational corporations with the development of public social services, while at the same time "controlling" the spread of the pioneer mining front. Nevertheless, the piece by Anne Péné-Annette on gold mining in Bolívar State ("La relance de l'extraction minière dans la Guyanne vénézuélienne" ["The Resumption of Mining Activity in Venezuelan Guyana"]) comes as a reminder of the "environmental destruction and human wreckage" that may be wrought by extractivism on a nationwide scale.

Many researchers and activists are today offering not only critical appraisals of these types of industrial exploitation of natural resources but also alternative models for the relationship between nature, human society and economy, or indeed between North and South (Sandrine Tolazzi, "Ressources minières et énegétiques: le choc des discours" ["Energy and Mineral Resources: the Clash in Language"] and the article by Maristella Svampa or the book by Anna Bednik quoted in Franck Gaudichaud, "Ressources minières, 'extractivisme' et développement en Amérique latine: perspective critiques" ["Mining Resources, 'Extractivism' and Development in Latin America: Critical Perspectives"]). As in Ecuador, the Quechuan concept of "good living" (the Sumak Kawsay), together with the idea of leaving oil and minerals in the ground, particularly in areas of high biodiversity, is gaining ground in civil society and political circles while leaving unresolved the problematic tension between, on the one hand, protecting ecosystems and respecting local communities and, on the other, providing access for all and everyone to a higher standard of living. In Evo Morales' Bolivia, for example, although the "Buen Vívir" ethos continues to be a symbolic reference readily harnessed by the President, the country remains heavily dependent on the exploitation of gas and mining resources, the present development of which is propelled more by pressure from various corporations than by the proclaimed reconquering of national sovereignty (Claude Le Gouill; “Néo-développementalisme, 'buen vívir' et luttes corporatistes dans la politique minière du gouvernement d'Evo Morales, Bolivie [Neodevelopmentalism, 'Buen Vívir' and Corporatist Struggles in the Mining Policy of the Evo Morales government in Bolivia]).

4 The environmental question is irrevocably linked to any history of mining, since mining, as Michel Deshaies points out, has always had a "predatory" relationship with the environment ("Mines et environnement dans les Amériques; les paradoxes de l'exploitation minière" ["Mines and the Environment in the Americas: the Paradoxes of Mining"]). Certainly, small-time prospectors and mining companies relentlessly digging out resources for immediate profit and then leaving behind swathes of heavily polluted land have now disappeared, to be replaced by large mining enterprises operating under more regulated conditions. It is also the case that pressure from certain local communities and NGOs has obliged mining corporations to reduce their environmental impact and, at the same time, to engage more closely with the development of areas where they operate in an effort to become more "acceptable" and to reverse the negative image they project. Deshaies notes the paradox whereby big corporations encounter growing opposition on account of their impact on the environment precisely at a time when this impact has never been so contained. However this may be, the very scale of present-day mining projects means that their impact remains huge, even before one considers the problems involved in the rehabilitation of areas where exploitation has ceased or the risk of accidental 
catastrophe (as illustrated by the recent dramatic Mariana mining disaster in the Brazilian state of Minas Gerais).

5 The debate on the environmental consequences of mega mining projects is in full swing and has induced governments to take greater precautions by means of impact studies such as the strategic environmental evaluation on shale gas ordered by the Quebec government to which Christiane Gagnon and Majella-J Gauthier contributed ("Inventaire et vulnérabilité des basses-terres du Saint-Laurent (Quebec, Canada) face à l'exploitation du gaz de schiste" ["Inventory and Vulnerability of the Saint-Lawrence Lowlands with Relation to the Exploitation of Shale Gas"]). The study they helped to carry out identified zones of vulnerability, and should thereby lead to better territorial management in the course of the exploitation planned in Quebec. However, scientists have difficulty in situating their approach independently of pre-positioned discourse when it comes to stakes of this nature. Easily identified is the rhetoric that aims to play down the impact of large development projects or even to present them as beneficial to the environment. Samuele Furfari, for example, argues not only that "in spite of its environmental impact, fossil energy has had extraordinarily positive repercussions on the conditions of our work, life and health", but also presents shale gas as a solution for the reduction of greenhouse gas emissions (Sandrine Tolazzi "Ressources minières et énergétiques: le choc des discours" ["Energy and Mineral Resources: the Clash in Language"]). On that premise, opponents of shale gas development are portrayed as people ill-informed about the processes of exploration and extraction (RTI International in the same article). Also easily identified is the discourse that involves clear recognition of the environmental impacts of the development of mined resources while presenting them as the main challenge to address in the construction of a global strategy of mined resources (Norman Mousseau, in the same article). The question then is whether to focus on the reduction of the environmental impact of mining projects or purely and simply to halt them in favor of an ecological transition.

6 Another consideration is how the exploitation of resources increasingly involves local actors who have reached a greater awareness of their status as an exploited or sacrificial minority. The fact that deposits are now being discovered in mountainous areas, historically a refuge for poorer, and usually indigenous populations has made these inhabitants of new mining areas realize that they were being despoiled and had been for many a year. Local ethnic groups assume greater political visibility when they begin to oppose state decision-makers perceived as belonging to a different social and cultural group. In Latin America, there has been a resurgence of old ethnic identities placed in abeyance in a context of assimilation and denigration of "Indians", with the term Indio often taken to be well-nigh injurious. Over the last fifteen years, peasant communities that are indigenous in the sense of the UN Declaration of the Rights of Indigenous Peoples, have been increasingly standing against mining projects and demanding greater local benefits from corporations, including a share in profits made. The article by Carmen Salazar-Soler ("La place de l'ethnicité dans les conflits miniers sociaux-environnementaux dans les Andes du Pérou, $\mathrm{XX}^{\mathrm{e}}-\mathrm{XXI}^{\mathrm{e}}$ siècles" ["Ethnic factors in $20^{\text {th }}$ and $21^{\text {st }}$ century socio-environmental mining conflicts in the Peruvian Andes"]) highlights this new awareness together with the demands of indigenous peoples regarding both an effective control of pollution and participation in decisions concerning the exploitation and use of natural resources in their territory. 
7 For Lucie Genay ("L'extraction d'uranium au Nouveau-Mexique: un symbole de la conquête par l'atome" ["Uranium Mining in New Mexico: a Symbol of the Triumph of the Atom"]), the mineral extraction being carried out in indigenous and Hispanic territories in New Mexico can be assimilated to conquest and colonization. Genay describes the vulnerability of the inhabitants of these mining areas where the economy is destabilized by the cyclical nature inherent in the exploitation of the resource. On the social side, she notes how, in areas of uranium deposits, a heritage of dependence and inequality persists despite activist efforts which, though robust, lack concentrated cohesiveness.

8 Ecological activism is a long-established phenomenon in the American West, where it derived from preservationist movements and the creation of the first national parks at the turn of the nineteenth century. The vision of nature embodied in this tradition is to be found in militant opposition to mining activity. Sites possessing high visibility, be it a national park, an otherwise protected area or a sacred mountain, tend to become focal points for such opposition, a fact evident in the very strong opinions of the Navajo and Laguna nation-tribes (Susanne Berhtier-Folgar, "L'exploitation des ressources minières de l'Ouest américain" ["The Exploitation of Mineral Resources in the America, West"] and Lucie Genay's article).

Beyond the confines of the United States, international activist organizations also take up the cause of despoiled and oppressed peoples worldwide. Distant as they are from immediate social and economic context, such expressions, though they do have the merit of alerting public opinion, are not always especially effective. And anyway, in the field, economic and military considerations trump the protection of nature. Susanne Berthier-Folger's study ("Ressources minières et énergétiques: Evolution et constance des défis" ["Mineral and Energy Resources: Constant and Shifting Challenges"]) relates how the owners of a uranium mine deep in the Grand Canyon were able to obtain permission for intrusive exploitation at the edge of a cliff only a few hundred meters from a tourist observation platform. During the Cold War, national defense and the arms race were considered far more important than the pristine nature of a national park.

It appears that the exploitation of mineral and energy resources is a central question for an understanding of certain economic, developmental models and of the balance of forces at play. Its attraction for researchers lies in its multi-layered relevance, from the individual - as may be seen from the images by photographer Louie Palu (interview with Lucie Genay) - to the community, via governmental and industrial actors, together with an economic and environmental impact that may be measured in local, regional or global terms. It is indeed a strategic question for the Americas and the articles selected here constitute an initial presentation of certain aspects of this vast field of study. 


\section{AUTHORS}

\section{SUSANNE BERTHIER-FOGLAR}

Susanne Berthier-Foglar est professeur, spécialiste de l'Ouest américain et des peuples autochtones, Université Grenoble Alpes (ILCEA4). susanne.berthier@univ-grenoble-alpes.fr

\section{FRANCK GAUDICHAUD}

Franck Gaudichaud est maître de conférences en histoire et civilisation de l'Amérique Latine à l'Université Grenoble Alpes et membre de l'ILCEA4 (EA 7356). franck.gaudichaud@univ-grenoblealpes.fr

\section{SANDRINE TOLAZZI}

Sandrine Tolazzi est maître de conférences à l'Université Grenoble Alpes (UFR des Langues, ILCEA4 - Institut des Langues et des Cultures d'Europe, Amérique, Afrique, Asie et Australie). sandrine.tolazzi@univ-grenoble-alpes.fr 